\title{
Ultrasonography and theloscopy for the diagnosis of obstructive fibrosis in the Fürstenberg venous ring in the four quarters of the udder of a cow: a case report
}

\author{
[Ultrassonografia e teloscopia no diagnóstico de fibrose obstrutiva do anel venoso \\ de Fürstenberg em quatro quartos mamários em bovino: relato de caso] \\ F.G. Miranda ${ }^{1}$, R.W. Cabala ${ }^{1}$, J.A.M. Lima ${ }^{1}$, A.C. Nepomuceno ${ }^{2}$, R.C.S. Tôrres ${ }^{2}$, V.A. Gheller ${ }^{2}$ \\ ${ }^{1}$ Aluna de pós-graduação - Universidade Federal de Minas Gerais - UFMG - Belo Horizonte, MG \\ ${ }^{2}$ Universidade Federal de Minas Gerais - UFMG - Belo Horizonte, MG
}

\begin{abstract}
We report an unusual case of obstructive fibrosis of the venous ring of Fürstenberg in all four quarters of the udder of a cow of the Girolando breed (3/8 Gir and 5/8 Dutch). The information was obtained through a review of medical records, anamnesis, and imaging methods such as theloscopy and ultrasonography. Histopathological analysis provided a definitive diagnosis.
\end{abstract}

Keywords: Girolando, teats, endoscopy, ultrasound

\section{RESUMO}

Relata-se a ocorrência de um caso incomum de fibrose obstrutiva do anel venoso de Fürstenberg em quatro quartos mamários de uma vaca da raça Girolando (3/8 Gir e 5/8 Holandês). As informações foram obtidas por meio de revisão do prontuário, da anamnese e de métodos de diagnóstico por imagem, como a teloscopia e a ultrassonografia. A análise histopatológica forneceu o diagnóstico definitivo.

Palavras-chave: Girolando, tetos, endoscopia, ultrassom

\section{INTRODUCTION}

The bovine mammary gland consists of four quarters, each containing structures called the gland cistern (GC) and teat cistern (TC). The region that separates the GC from the TC consists of large venous vessels that make up the ring of Fürstenberg. Disorders of the teat reduce milk production and alter the quality of its components, necessitating treatment expenses and early disposal of affected animals, which ultimately has a negative economic impact (Franz et al., 2009).

Obstructive fibrosis (OF) of the teat is a common disorder that is notable because it interferes directly with milk flow (Agger e Hesselholt, 1986). OF is classified as either full or partial, and may be located in the proximal, medial, or distal regions of the teat (Franz et al., 2009).

Recebido em 10 de outubro de 2016

Aceito em 3 de dezembro de 2016

E-mail: fernandaguimaraes4@gmail.com
OF occurs predominantly in the TC region (Geishauser et al., 2005). In species with milk aptitude, OF of the TC represents $80 \%$ of all teat stenosis (Roine, 1975). Moreover, 89.3\% of traumatic injuries that can cause OF occur in Fürstenberg's rosette and in the sphincter (Frémon et al., 2002). The frequency of OF is lower in the venous ring than in the other regions of the teat (Roine, 1975; Frémon et al., 2002).

Ultrasonography has been routinely used in the diagnosis of OF, especially in determining the extent of injury (Mavrogianni et al., 2004). It is a non-invasive technique, does not use ionizing radiation, and allows the visualization of all the internal structures of the mammary gland, including the teat. Ultrasonographic images contribute to the diagnosis by allowing the identification of the location of the OF — which is often not achieved by physical examination alone. OF of the teat is among the main reasons for performing ultrasonography (Franz et al., 2009). 
Theloscopy is recommended for a quick diagnosis of lesions located inside the teat, especially lesions that commonly alter the flow of milk. It allows direct visualization of the mucosa, allowing inferences about the extent and severity of the injury (Rathod et al., 2009). The technique is commonly used for surgical interventions, with stenosis of the teat being one of the indications (Franz et al., 2009).

The aim of this study was to evaluate the diagnostic contribution of ultrasonography and theloscopy in an unusual case of OF in all four teats of a cow of the Girolando breed.

\section{CASE REPORT}

A cow of the Girolando breed (3/8 Gir and Dutch $5 / 8$ ), raised in a semi-intensive system (weight, $750 \mathrm{~kg}$; age, approximately 6 years), was referred to the ruminant sector of the clinic at the Veterinary Hospital of the University of Minas Gerais, with a history of agalactia.
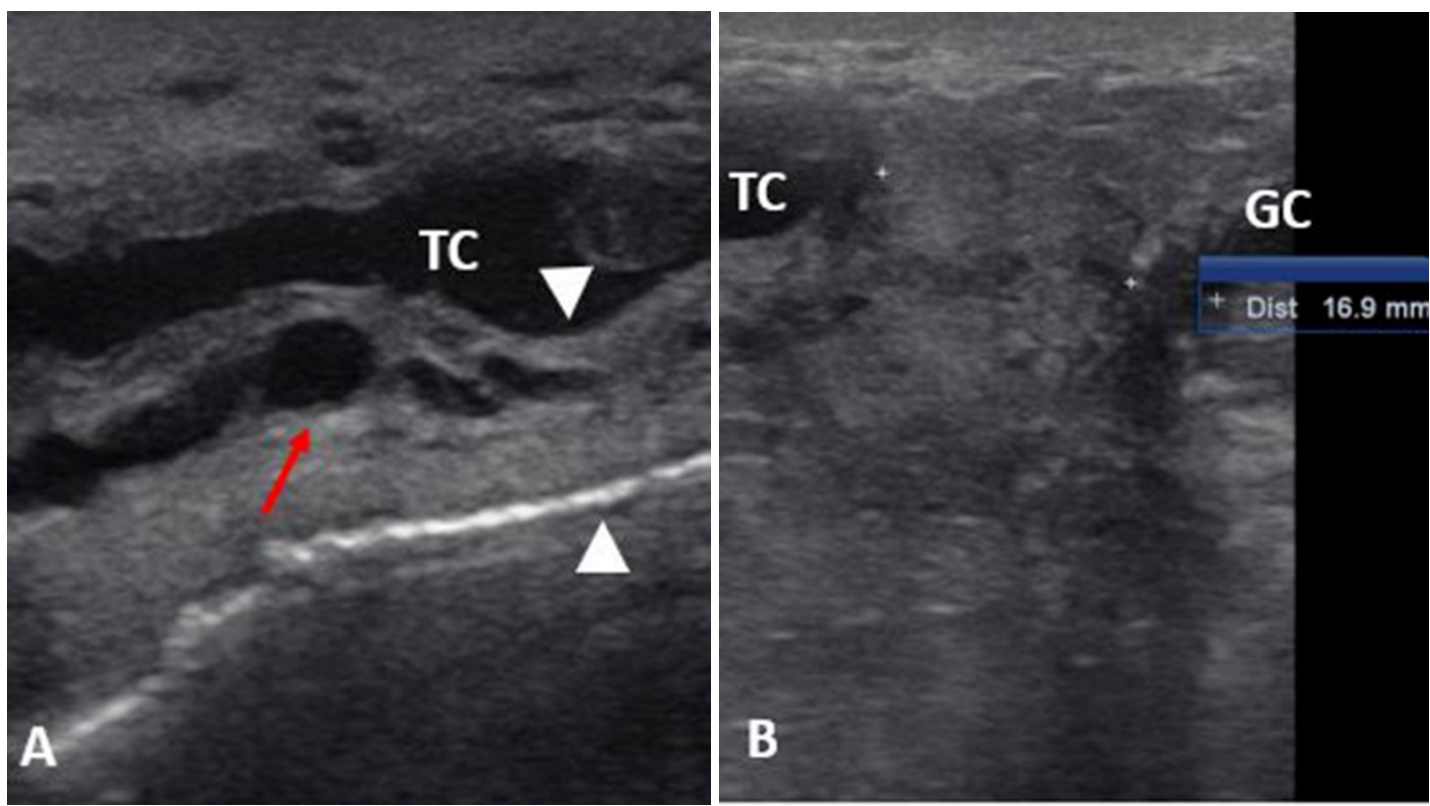

Figure 1. Ultrasonographic images of Girolando cow in the longitudinal plane showing A) the teat cistern (TC). The arrowheads demarcate the thickened wall. The red arrow shows the enlarged and tortuous vessel. B) Transition zone between the TC and gland cistern (GC), measuring approximately $1.69 \mathrm{~cm}$. Communication between both the cisterns is reduced. 
Axial theloscopy was performed by using a $30^{\circ}$, 2.7-mm-diameter rigid endoscope and a $3.5-\mathrm{mm}$ optical cable; a TELECAM SL camera; and a 300-W xenon light source for the endoscopy. After affixing a prostatic Doyen clamp to the base of the papilla, the TC was inflated with environmental air via the papillary orifice by using a sterile $10-\mathrm{mL}$ syringe attached to an air filter. Then, the hard endoscope was introduced through the papillary orifice for visualizing the mucosa, the inner surface of the proximal portion of the papillary orifice and the TC. The observation of stenosis in the four teats, at varying degrees, was compatible with obstruction of the venous ring of Fürstenberg (Figure 2)

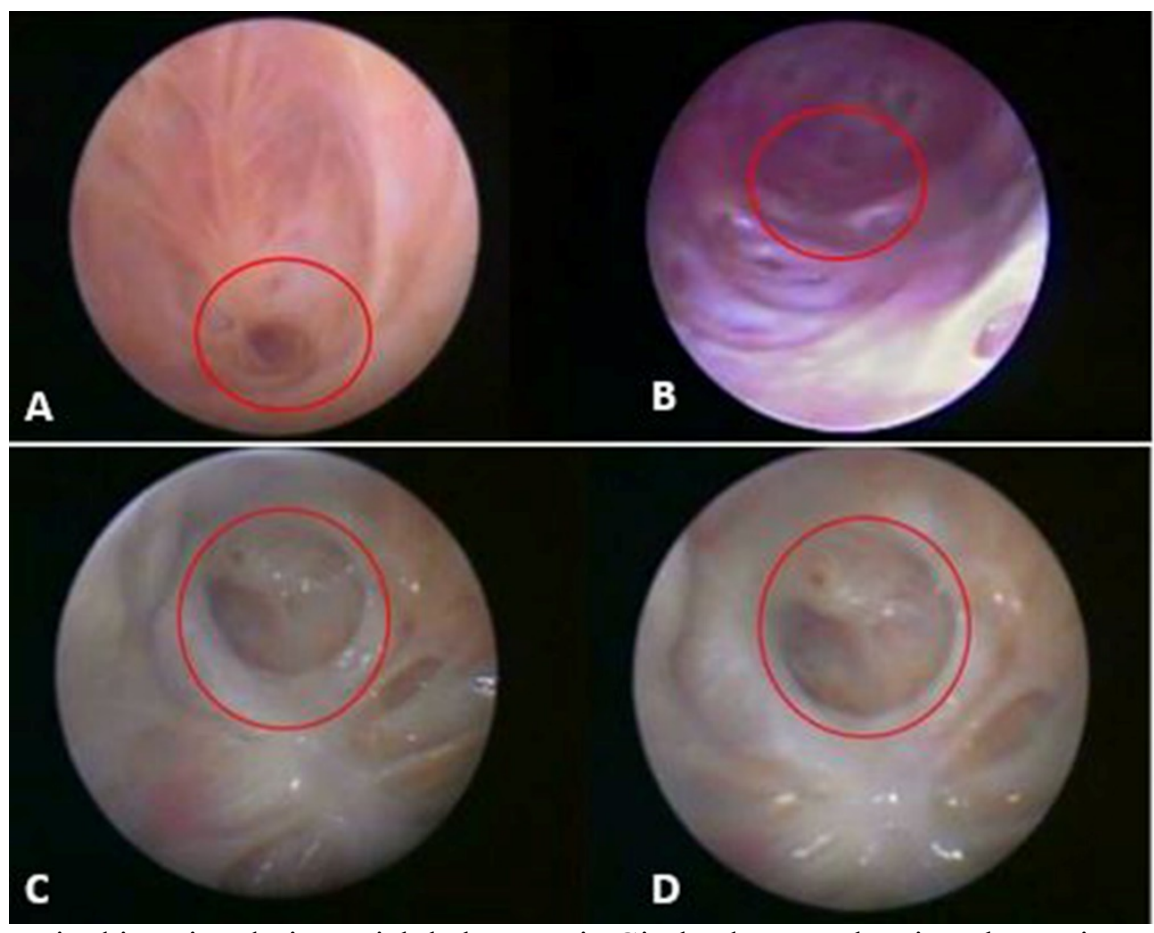

Figure 2. Acquired imaging during axial theloscopy in Girolando cow, showing obstruction of the venous ring of Fürstenberg (circle) in the right anterior teat (A), severe obstruction of the ring (circle) in the left anterior teat (B), and obstruction of the venous ring of Fürstenberg (circles) in the right (C) and left posterior teats (D).

After theloscopic inspection, tissue samples from the obstruction area of the venous ring of the Fürstenberg were collected through biopsy with the aid of a Biocore II biopsy needle, (12 $\mathrm{g} \times 12$ cm; MMdiagnóstika, São Paulo, SP, Brazil). The histopathological analysis revealed that the area of the obstruction was composed of fibrotic tissue. The final diagnosis was OF of the venous ring of Fürstenberg, whose occurrence is considered unusual in this region when compared to other regions of the teat.

In order to assess whether abnormalities in mammary secretory tissue coexisted, biopsy in the medial region of the anterior right quarter was also performed with the aid of a Biocore II biopsy needle. A topical intramammary antibiotic was applied to each quarter after the procedure.

The obtained tissue samples were later processed and stained with hematoxylin-eosin. Microscopic examination revealed cells with nuclei occupying a major proportion of the intracellular space and containing large cytoplasmic vesicles in a large part of the alveoli. In addition, the examination also revealed a substantial number of cells with morphological features of apoptosis, such as condensed nuclei and cell wall shrinkage, which causes loss of adhesion to the extracellular matrix of surrounding the cells (Figure 3). Through the histopathological analysis of the $\mathrm{GC}$, it was concluded that the alveoli were in a process of involution. 


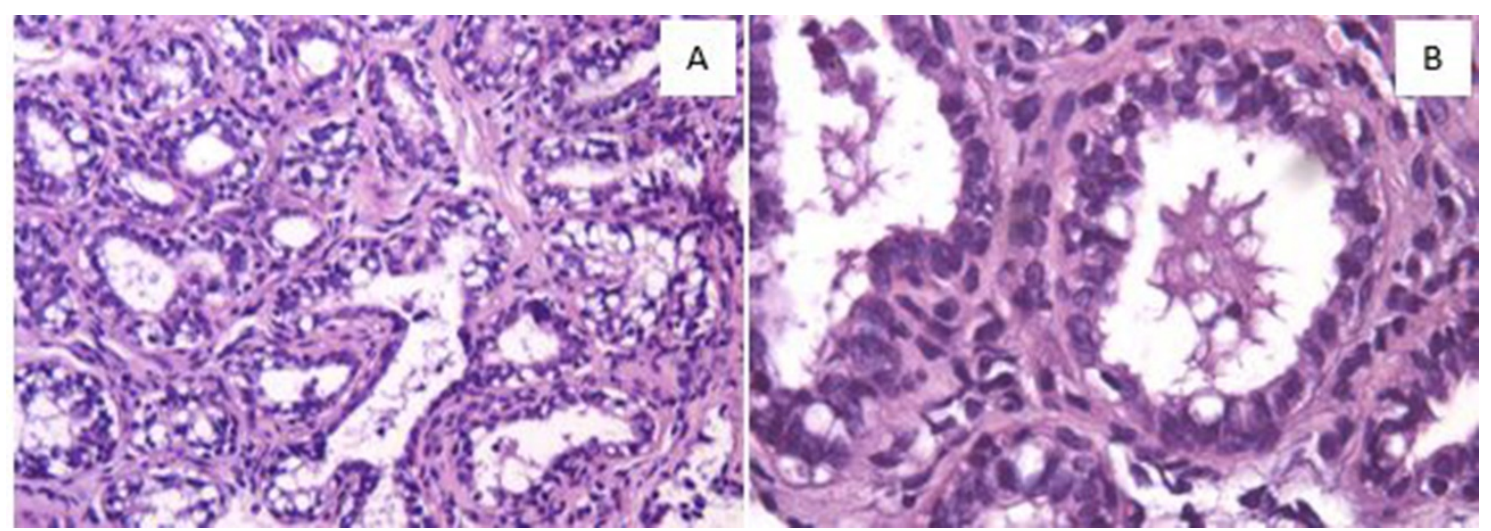

Figure 1. Histopathological image of the glandular mammary tissue of Girolando cow in which alveoli presenting cells with large nuclei and large cytoplasmic vesicles are seen (A), together with programmed cell death (apoptosis) (B).

\section{DISCUSSION}

Although udder and teat disorders are common in dairy cows, the frequency of OF is lesser in the venous ring of Fürstenberg than in other anatomical regions of the mammary gland (Frémon et al., 2002). To our knowledge, the profuse occurrence of OF in all four teats has not been reported previously.

Lesions inside the teats are frequent in dairy cows, and the majority of these lesions are caused by inappropriate cleaning and disinfection of milking facilities and equipment, or inadequate anatomical conformation of the udder. The main disorders affecting the mammary glands occur via the ascending pathway, that is, the pathogen enters the papillary orifice, passes through the conduit, reaches the $\mathrm{TC}$, and compromises the $\mathrm{TC}$ parenchyma (Nickerson, 1985).

The presence of Escherichia coli in the milk sample taken from the cow suggests that the pathogen responsible for the disease originated in the environment, suggesting poor hygiene and inadequate management in the milking parlor, pastures, and beds. In addition, environmental mastitis more often affects cows in the dry period and during early lactation (Hogan e Smith, 2012), which confirms the hypothesis of mastitis having been the cause of OF in this case

Ultrasonography may be indicated as a routine examination for the evaluation of mammary glands in cattle. In this case, the animal allowed the examination to take place without the need for chemical restraint through sedation and/or anesthesia. The anatomical mammary structures related to the $\mathrm{TC}$ and $\mathrm{GC}$, teat wall, and vascularizations were identified according to Franz et al. (2009), who described ultrasonography as an ideal non-invasive technique for evaluating clinical cases of suspected OF.

The decisive ultrasonographic finding for the diagnosis of $\mathrm{OF}$ was the visualization of reduced communication between the TC and GC, which was consistent with the firm area identified upon palpation at the base of the udder. Secondary signs of inflammation were also observed through vascular dilation and wall thickening $(10 \mathrm{~mm})$; a wall thickness of $10 \mathrm{~mm}$ is quite high compared to the average thickness of $7 \mathrm{~mm}$, according to Weiss et al. (2004).

Axial theloscopy confirmed the clinical and ultrasonographic findings through direct visualization of fibrous tissue in the structure of the venous ring of Fürstenberg, which severely reduced the communication between the TC and GC. The technique was considered applicable and efficient, both in establishing the diagnosis and in characterizing the severity and extent of the injury as described by Rathod et al. (2009).

The main diagnostic contribution of theloscopy in this case was the findings showing interruption of the flow of milk from the GC to TC. Histopathological examination of the GC showed cell apoptosis, which is also identified in 
the end lactation phase and which, according to Capuco et al. (2002), causes involution in the productive tissue. In the present case, these characteristics may be related to the process of involution of the mammary gland because of milk stasis resulting from the OF.

\section{CONCLUSIONS}

OF of the venous ring of Fürstenberg is a rare condition that may result in agalactia. To our knowledge, its occurrence in all four mammary quarters has not been previously reported. The ultrasonographic and theloscopic findings were useful in the characterization of lesions, and, combined with histopathological examination, helped confirm the clinical suspicion of milk flow interruption between the GC and TC as a result of OF of the venous ring of Fürstenberg

\section{REFERENCES}

AGGER, J.F.; HESSELHOLT, M. Epidemiology of teat lesions in a dairy herd. I: Description of the incidence, location and clinical appearance. Nord. Vet. Med., v.38, p.209-219, 1986.

CAPUCO, A.V.; LI, M.; LONG, E. et al. Concurrent pregnancy retards mammary involution: effects on apoptosis and proliferation of the mammary epithelium after forced weaning of mice. Biol. Reprod., v.66, p.1471-1476, 2002.

FRANZ, S.; FLOEK, M.; HOFMANNPARISOT, M. Ultrasonography of the bovine udder and teat. Vet. Clin. Food Anim., v.25, p.669-685, 2009.
FRÉMONT, A.; BERGONIER, D.; BERTHELOT, X. et al. I'Intérêt de l'endoscopie pour le diagnostic et le traitement des sténoses du trayon chez la vache laitiére: étude d'un cas clinique. Rev. Med. Vet., v.153, p.40-46, 2002.

GEISHAUSER, T.; QUERENGA“SSER, K.; QUERENGASSER, J. Teat endoscopy (theloscopy) for diagnosis and therapy of milk flow disorders in dairy cows. Vet. Clin. Food Anim., v.21, p.205-225, 2005.

HOGAN, J.; SMITH, K.L. Managing environmental mastitis. Vet. Clin. Food Anim., v.28, p.217-224, 2012.

MAVROGIANNI, V.S.; FTHENAKIS, G.C.; BURRIEL, A.R. et al. Experimentally induced teat stenosis in dairy ewes: clinical, pathological and ultrassonographic features. J. Comp. Pathol., v.130, p.70-74, 2004.

NICKERSON, S.C. Immune mechanism of the bovine udder: an overview. J. Am. Vet. Med. Assoc., v.187, p.41-45, 1985.

RATHOD, S.U.; KHODWE, P.M.; RAIBOLE, R.D.; VYAVAHARE, S.H. Theloscopy- the advancement in teat surgery and diagnosis. Vet. World, v.2, p.34-37, 2009.

ROINE, K. Observations on teat stenosis. Nord. Vet. Med., v.27, p.107-111, 1975.

WEISS, D.; WEINFURTNER, M.; BRUCKMAIER, R.M. Teat anatomy and its relationship with quarter and udder milk flow characteristics in dairy cows. J. Dairy. Sci., v.87, p.3280-3289, 2004. 